\title{
ПІДТРИМКА ПРИЙНЯТТЯ РІШЕНЬ ПЕРСОНАЛУ ЕЛЕВАТОРА ОЛІСЕКСТРАКЦЙНОГО ЗАВОДУ 3 ОПТИМАЛЬНОГО УПРАВЛІННЯ ЗАПАСАМИ ОЛІЙНОЇ СИРОВИНИ
}

\author{
Світий I.M. ${ }^{1}$ \\ ${ }^{1}$ Одеська національна академія харчових технологій, Одеса
}

Copyright (C 2014 by author and the journal “Automation technological and business - processes". This work is licensed under the Creative Commons Attribution International License (CC BY). http://creativecommons.org/licenses/by/4.0/

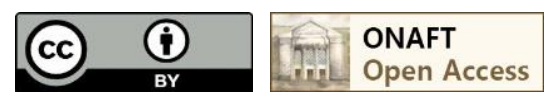

DOI: $10.15673 / 2312-3125$.

\begin{abstract}
Анотація
Проаналізовано ринок виробництва олії в Україні та можливість підвищення ефективності роботи підприсмств-виробників за рахунок удосконалення системи управління запасами насіння. Обгрунтовано доцільність підвищення інтелектуального рівню підтримки прийняття рішень персоналу елеватора олісекстракційного та оліспресового заводу. Проаналізовано основні обов'язки персоналу елеватора, пов'язані з необхідістю прийняття рішень на етапах розміщення насіння на зберігання, зберігання насіння, його обробки та формування відпускних партій. Сформульовано підходи та критерії до виявлення ситуацій, що вимагають прийняття рішень, формування альтернативних варіантів рішень та визначення їх корисності на етапах розміщення насіння на зберігання, зберігання в силосах, обробки та формування відпускних партій. Сформульовано універсальний показник корисності варіанту рішення. Визначення показника корисності на етапі розміщення насіння здійснюється в два етапи: для пустих силосів - у залежності від пріоритетності заповнення силосів, за відсутності пустих силосів - за показником дисперсності параметрів розміщуваної партії насіння та партій насіння, що зберігаються. На етапі зберігання насіння опрацьовано питання виявлення силосів, у яких спостерігаються процеси нерегламентованої активності, сформульовано критерій виявлення ситуації, що вимагає прийняття рішень 3 оцінкою актуальності ситуації. На етапі обробки насіння сформульовано принцип пошуку оптимальних режимних параметрів технологічного процесу за економічною ефективністю, ступенем рентабельності та компромісним критерієм, сформульовано показник корисності варіантів рішення у прив'язці до указаних вище критеріїв. На етапі формування відпускних партій насіння сформульовано показник корисності варіанту рішення у залежності від дисперсності параметрів партій насіння, що зберігаються, та бажаних параметрів відпускної партії. Сформульовані підходи було практично реалізовано у вигляді програмного продукту для тестового об'скту: елеватора насіння Одеського олісекстракційного заводу. Результати тестування алгоритмів підтримки прийняття рішень показали їх ефективність та доцільність для практичного впровадження. В якості результатів роботи визначено статті підвищення економічної ефективності функціонування підприємства, пов'язані 3 впровадженням результатів роботи у вигляді програмного продукту. До цих статей відносяться: зниження впливу людського фактору; зниження втрат, пов'язаних 3 нерівномірністю за якісними показниками партій зерна, що зберігаються; зменшення експлуатаційних затрат на обслуговування будівель і обладнання; зменшення втрат насіння в масі і якості при зберіганні; зменшення імовірності прийняття недостатньо ефективних рішень, підвищення ефективності технологічних процесів за рахунок пошуку економічно доцільних режимних параметрів;
\end{abstract}




\section{5 ТЕОРІЯ I ПРАКТИКА АВТОМАТИЗАЦІЇ БІЗНЕС-ПРОЦЕСІВ}

підвищення ефективності основних технологічних процесів виробництва олії за рахунок максимально точного відтворення бажаних якісних показників у відпускних партіях насіння.

\section{Abstract}

The market of production of butter in Ukraine and possibility of increase of efficiency of work of enterprisesproducers is analysed due to the improvement of control system by supplies seed. Grounded expedience of increase intellectual the level of support of making decision personnel of elevator of oil-extraction and oil-press factory. It is analysed the basic obligatory personnel of elevator, it is connected with the necessity of making decision on the stages of placing of seed on storage, storage of seed, their treatment and forming of vacation parties. Going and criteria is formulated near the exposure of situations, which require making decision, forming of alternative variants of decisions and determination of their utility, on the stages of placing of seed on storage, storage, in silos, treatment and forming of vacation parties. The universal index of utility of variant of decision is formulated. Determination of index of utility on the stage of placing of seed is carried out in two stages: for empty silos - in dependence on priority of filling of silos, in default of empty silos - after the index of dispersion of parameters of the placed party of seed and parties of seed, which are kept. On the stage of forming of vacation parties seed are formulated index of utility of variant of decision in dependence on dispersion of parameters of parties of seed, which are kept, and desired parameters of a vacation party. The formulated approaches were practically realized as a software product for object test: elevator of seed of the Odesa oil-extraction factory. The results of testing of algorithms of support of making decision were rotined by their efficiency and expedience for practical introduction. In quality job performances the articles of increase of economic efficiency of functioning of enterprise are certain, it is connected with introduction of job performances as a software product. To these articles belong: decline of influence of human factor; decline of losses, it is connected with an unevenness on the high-quality indexes of parties of grain, which are kept; diminishing of operating costs is on maintenance of buildings and equipment; there is diminishing of losses of seed in-bulk and quality at storage; diminishing of probability of acceptance not enough of effective decisions, increase of efficiency of technological processes, is due to a search economic of expedient regime parameters; an increase of efficiency of basic technological processes of production of butter is due to the maximally exact recreation of the desired high-quality indexes in vacation parties of seed.

Ключові слова

Виробництво соняшникової олії, елеватор, підтримка прийняття рішень, підходи, критерії.

Вступ

Соняшникова олія $є$ цінним харчовим продуктом 3 високою енергетичною цінністю, сировиною для виробництва харчових продуктів (хліба, овочевих, м'ясних, рибних консервів, тощо), кормів для тварин (в формі рідкої добавки або шроту). За даними інтернет-порталу UBR [1], Україна входить у трійку найбільших виробників соняшникової олії у світі, будучи лідером за обсягом його поставок на зовнішні ринки із часткою понад $50 \%$. В 2011/2012 маркетинговому році Україна виробила 3,65 млн. т соняшникової олії, 3 яких 3,2 млн. т було експортовано. Отже, олія для України є важливим джерелом валютних надходжень.

Виробництво соняшникової олії в Україні здійснюється на олієекстракційних та олієпресових підприємствах. За даними інтернет-порталу UBR [1] в нашій країні спостерігається надлишок виробничих потужностей 3 переробки насіння соняшника на фоні введення нових виробничих потужностей. За таких умов зможуть вижити підприємства, здатні забезпечувати низьку собівартість виробництва.

\section{Визначення задачі}

Олієекстракційні та олієпресові підприємства належать до групи підприємств, робота яких пов'язана 3 накопиченням олієвмісної сировини у значних обсягах в сховищах силосного типу. Для таких підприємств існує шлях підвищення економічної ефективності, що пов'язаний з підвищенням ефективності управління запасами сировини. На переважній більшості підприємств такого типу управління запасами сировини ведеться практично "вручну" 3 використанням досвіду обслуговуючого персоналу. Частково автоматизованою $є$ інформаційна підтримка оператора. А у прийнятті рішень (у реалізації керуючих дій) оператор підтриманий, у кращому випадку, методично (тобто, на передових підприємствах існують достатньо детальні технологічні інструкції з ведення процесів на елеваторі). При цьому процес прийняття рішень здійснюється в умовах значного обсягу інформації про наявність та стан партій насіння, що постійно змінюється. Отже, ведення цього процесу в ручному режимі 
пов'язане зі значною імовірністю прийняття оператором економічно (або технологічно) недостатньо ефективних рішень. Якщо олійна сировина представлена різними олійними культурами (насіння соняшника, соя, тощо), існує імовірність прийняття помилкових рішень, пов'язаних зі змішуванням різних культур. А, зважаючи на значні обсяги сировини в силосах, помилкові та неефективні рішення оператора призводять до суттєвих економічних збитків підприємства в цілому. Отже, очевидним джерелом підвищення економічної ефективності олієекстракційних та олієпресових підприємств $є$ підвищення ефективності прийняття рішень персоналом елеватора підприємства за рахунок підвищення інтелектуального рівню підтримки прийняття рішень.

В якості тестового об'єкту було прийнято елеватор Одеського олієекстракційного заводу, що містить силоси квадратного перерізу з розмірами 3Х3Х30м. Силоси по 10 шт. вибудувані в 6 рядів: загальна кількість силосів 60 шт. Місткість силосу $270 \mathrm{~m}^{3}$, загальна місткість зерносховища складає $16200 \mathrm{~m}^{3}$. У один силос в середньому (натура 550г/л) може розміститися 150 т насіння, а в елеваторі в цілому - майже 9 тис. т. При продуктивності підприємства в 730 т/доб. повністю заповненого елеватора вистачить на 12 діб роботи підприємства. Тобто очевидною $\epsilon$ необхідність постійного контролю за запасами насіння та своєчасного їх поповнення. "Ручне" управління запасами насіння у таких умовах не дозволяє вести технологічний процес з максимально можливою ефективністю.

Концепція організації підтримки прийняття рішень.

Робота виробничого персоналу елеватора (начальника елеватора, начальника зміни, майстрів) пов'язана 3 прийняттям рішень: 3 розміщення партій сировини на постійне чи тимчасове зберігання; з обробки сировини, закладеної на тимчасове зберігання, та закладання іiї на постійне зберігання; з контролю за станом зернових мас при зберіганні; з обробки сировини у випадку нерегламентованого зберігання зернових мас; з формування партій сировини на виробництво.

Підвищення ефективності прийняття рішень на етапі приймання та розміщення насіння пов'язане зі створенням максимально рівномірних за основними параметрами партій насіння в силосах або бункерах тимчасового чи постійного зберігання. Підвищення ефективності прийняття рішень з обробки насіння пов'язане 3 формуванням своєчасних економічно обгрунтованих команд з направлення насіння на обробку та формування економічно доцільних режимних параметрів процесів обробки насіння (наприклад, оптимальних режимів сушіння). Підвищення ефективності прийняття рішень при зберіганні насіння пов'язане з ранньою діагностикою процесів самозігрівання нерегламентованої інтенсивності та з оцінкою можливого впливу технологічних заходів 3 догляду за насінням, яка реалізується з позиції ефективності впливу саме на біологічні процеси, що протікають в масі насіння. Підвищення ефективності прийняття рішень при формуванні відпускних партій насіння на виробництво пов'язане з забезпеченням параметрів відпускних партій, максимально близьких до заданих кондицій.

Отже, в задачі підтримки прийняття рішень персоналу складу сировини об'єктом прийняття рішень є маси олієвмісної сировини, що приймаються, розміщуються, зберігаються, обробляються на елеваторі, а також відвантажуються на виробництво. Особою, що приймає рішення (ОПР), є виробничий персонал елеватора. Ситуації, що вимагають від ОПР прийняття рішень (СПР), вирізняються за етапом виробничого процесу. На етапі приймання та розміщення зерна СПР полягає в надходженні нової партії насіння на прохідну підприємства (автомобіль, вагон, судно, тощо). Іноді вважають, що на етапі приймання насіння СПР присутня, якщо біля прохідної накопичилася черга 3 декількох автомобілів. На етапі обробки насіння СПР полягає в накопиченні економічно обгрунтованої для обробки кількості насіння. На етапі зберігання насіння СПР присутня, якщо виявлено зернові маси, в яких протікають біологічні процеси нерегламентованої інтенсивності. На етапі відвантаження насіння на виробництво СПР полягає в необхідності сформувати відпускну партію насіння 3 заздалегідь заданими параметрами.

За наявності ситуації, що вимагає прийняття рішень, виникає необхідність у процесі підтримки прийняття рішень. Суть процесу полягає в напрацюванні альтернативних варіантів рішення, в оцінці корисності кожного варіанту та у формуванні рекомендацій щодо реалізації найбільш корисного варіанту.

Під варіантом рішення на етапі приймання насіння будемо розуміти силос (або силоси), у якому може бути розміщена партія насіння. Вибір можливого варіанту рішення в цьому випадку здійснюється в два етапи. На першому етапі обираються пусті силоси, а на другому етапі вже частково заповнені. Пріоритетність у заповненні пустих силосів пов'язана 3 необхідністю рівномірного навантаження на будівничі конструкції (головним чином, фундамент) елеватора. Оцінка корисності варіанту здійснюється за показником корисності $J_{i}$, пронормованим в долях одиниці. Розрахунок цього показника здійснюється на основі пріоритетного номера силосу ПН ${ }_{i}=1 \ldots n$ (де $n$ - загальна кількість силосів у зерносховищі). Показник корисності варіанту рішення може бути вирахуваний за залежністю:

$$
J_{i}=1 / \Pi \mathrm{H}_{i}
$$

Другий етап пошуку варіантів рішення 3 вибору силосу для розміщення партії насіння, що надійшла, розпочинається, якщо не виявлено ні одного пустого силосу. При цьому виявляються силоси, у яких зберігається 


\section{$\underline{5}$ ТЕОРІЯ І ПРАКТИКА АВТОМАТИЗАЦІЇ БІЗНЕС-ПРОЦЕСІВ}

та ж олійна сировина, що і поступила в розміщуваній партії. Якщо на підприємстві впроваджено систему простежуваності [2], то при виборі варіанту рішення накладається обмеження на приймання сировини того ж виробника. Окрім того, при пошуку можливих силосів для розміщення зерна накладається обмеження на розбиття розміщуваної партії зерна по кількох силосах (розміщувана партія зерна повинна поміститися до силоса цілком). При виконанні усіх обмежень проводиться розрахунок показника дисперсії параметрів партії насіння, що зберігається, та розміщуваної партії насіння. Якщо $\vec{P}=\left\{P_{1}, P_{2} \ldots P_{m}\right\}$ - параметри розміщуваної партії зерна, $\vec{Z}_{i}=\left\{Z_{1 i}, Z_{2 i} \ldots Z_{m i}\right\}$, параметри і-ї партії зерна, що зберігається, то показник дисперсії параметрів за і-м варіантом рішення визначатиметься наступним чином:

$$
D_{i}=\sum_{j} a_{j} \cdot\left|P_{j}-Z_{j i}\right|,
$$

де $a_{j}$ - масштабний коефіцієнт, покликаний урівняти вплив окремих складових критерію на його кінцеве значення. Показник корисності варіанту рішення може бути вирахувано за залежністю:

$$
J_{i}=1 / D_{i}
$$

На етапі зберігання насіння виявлення ситуації, що вимагає прийняття рішень грунтується на прогнозуванні протікання біологічних процесів з урахуванням їх активності в залежності від умов зберігання насіння. В результаті протікання цих процесів втрачається маса сухих речовин. Якщо прогнозовані втрати сухої речовини $\Delta \mathrm{M}_{\Pi}[3]$ перевищують норми природних втрат $\Delta \mathrm{M}_{\mathrm{H}}[4]$, тобто

$$
\Delta \mathrm{M}_{\Pi}>\Delta \mathrm{M}_{\mathrm{H}}
$$

то це означає, що присутня ситуація, що вимагає від ОПР прийняття рішень. Але ж для великої кількості зернових мас, що характерно для елеваторів з залізобетонними силосами, цілком імовірною є ситуація наявності кількох ситуацій, що вимагають прийняття рішень. Тому після виявлення таких ситуацій доцільно їх відранжувати, наприклад, за показником критичності ситуації:

$$
\mathrm{R}=\Delta \mathrm{M}_{\Pi}-\Delta \mathrm{M}_{\mathrm{H}}
$$

Відомо [3], що далеко не всі ситуації, що вимагають прийняття рішень, доцільно відпрацьовувати 3 економічної точки зору, оскільки вплив варіантів рішення, що приводить до зниження втрат в масі насіння, у вартісному еквіваленті може бути меншим від витрат на реалізацію цього варіанту рішення.

$$
\mathrm{E}_{\mathrm{ij}}=\left(\Delta \mathrm{M}_{\Pi \mathrm{i}}-\Delta \mathrm{M}_{\Pi \mathrm{ij}}\right) \cdot Ц_{\mathrm{i}}-3_{\mathrm{j}}<0,
$$

де $\Delta \mathrm{M}_{П і}$ - прогнозовані втрати в масі насіння при і-й ситуації, що вимагає прийняття рішень; $\Delta \mathrm{M}_{П \mathrm{ij}}-$ прогнозовані втрати в масі насіння при і-й ситуації після застосування ј-го варіанту рішення; Ц - вартість одиниці маси насіння; $3_{j}$ - витрати на реалізацію ј-го варіанту рішення. Надалі ОПР потрібно сформувати набір актуальних ситуації, що вимагають прийняття рішень. У цей набір повинні входити ситуації у порядку зменшення показника критичності ситуації 3 виключенням ситуацій, для яких не існує жодного варіанту рішення 3 позитивним показником економічної ефективності.

Надалі ОПР повинна обрати ситуацію, яку буде відпрацьовувати. На етапі зберігання насіння під варіантом рішення слід розуміти комплекс технологічних заходів з обробки насіння з урахуванням режимних параметрів реалізації технологічних процесів. Режимні параметри обирають у відповідності до технологічної інструкції. Від

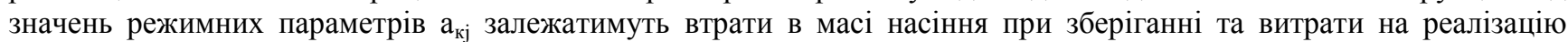
варіанту рішення, тобто $\Delta \mathrm{M}_{\text {Пij }}=\mathrm{f}_{1}\left(\mathrm{a}_{\mathrm{kj}}\right)$ та $3_{\mathrm{j}}=\mathrm{f}_{2}\left(\mathrm{a}_{\mathrm{kj}}\right)$. Критеріями для розрахунку корисності варіанту рішення можуть слугувати показник економічної ефективності (6) та показник рентабельності варіанту рішення $\mathrm{P}_{\mathrm{j}}$, який можна визначити, як:

$$
P_{j}=E_{i j} / 3_{j}
$$

Корисність варіанту рішення для етапу зберігання зерна доцільно визначати наступним чином:

$$
J_{j}=\frac{E_{i j}}{\max _{j}\left(E_{i j}\right)} \text { або } J_{j}=\frac{P_{j}}{\max _{j}\left(P_{j}\right)} \text { або } J_{j}=\frac{\frac{E_{i j}}{\max _{j}\left(E_{i j}\right)}+c \cdot \frac{P_{j}}{\max _{j}\left(P_{j}\right)}}{1+c},
$$




\section{$\underline{5}$ ТЕОРІЯ І ПРАКТИКА АВТОМАТИЗАЦІї БІЗНЕС-ПРОЦЕСІВ}

де $\max _{j}\left(E_{i j}\right), \max _{j}\left(P_{j}\right)_{-}$максимальне значення показника економічної ефективності та показника рентабельності серед усіх варіантів рішення у ситуації прийняття рішення, що відпрацьовується; $c$ - коефіцієнт компромісу між показником економічної ефективності та показником рентабельності. Отримані варіанти рішення надаються ОПР відранжованими за заздалегідь обраним показником корисності (7).

На етапі обробки насіння суть прийняття рішення полягає в пошуку оптимальних режимних параметрів реалізації технологічних процесів. Під ситуацією, що вимагає прийняття рішень, будемо розуміти наявність партії насіння, що зберігається, для якої виявлена ситуація у відповідності до (4), (5) та (6). Оскільки існують залежності $\Delta \mathrm{M}_{\text {Пij }}=\mathrm{f}_{1}\left(\mathrm{a}_{\mathrm{kj}}\right)$ та $3_{\mathrm{j}}=\mathrm{f}_{2}\left(\mathrm{a}_{\mathrm{kj}}\right)$, якщо прийняти лінійність цих залежностей, то на основі (6) очевидна залежність $\mathrm{E}_{\mathrm{ij}}=$ $\mathrm{f}\left(\mathrm{a}_{\mathrm{kj}}\right)$, яка матиме екстремум (максимум). Отже задача пошуку оптимальних режимних параметрів може бути зведена до оптимізаційної задачі виду:

$$
\begin{gathered}
a_{K j}^{*}=\underset{\text { або }}{\arg \max }\left[E_{i j}\left(a_{K j}\right)\right] \\
a_{K j}^{*}=\arg \max \left[P_{j}\left(a_{K j}\right)\right] \\
a_{K j}^{*}=\arg \max \left[E_{i j}\left(a_{K j}\right)+c_{1} \cdot P_{j}\left(a_{K j}\right)\right],
\end{gathered}
$$

де $c_{1}$ - коефіцієнт компромісу.

На етапі відвантаження насіння на виробництво суть прийняття рішення зводиться до формування відпускної партії насіння з наперед заданими параметрами. В якості ситуації, що вимагає прийняття рішення, слід розглядати наявність планового завдання на відвантаження партії насіння на виробництво. Під варіантом рішення слід розуміти партії насіння, що зберігаються в силосах. Якщо відвантажувальна партія насіння повинна мати масу, яка значно менша від максимальної маси насіння в одному силосі, то відпускну партію зерна доцільно формувати повністю з одного силосу. При цьому корисність варіанту рішення доцільно визначати за залежністю (3), а показник дисперсності - наступним чином:

$$
D_{i}=\sum_{j} a_{j} \cdot\left|V_{j}-Z_{j i}\right|,
$$

де $V_{j}$ - параметри відпускної партії насіння.

Якщо відвантажувальна партія насіння повинна мати масу, порівняну з максимальною масою насіння в одному силосі або більшу від неї, то відпускну партію зерна доцільно формувати змішуванням якомога меншої кількості партій насіння, що зберігаються. На першому етапі відбувається пошук двох (чи більше) партій насіння 3 максимально близькими за показником дисперсності параметрами (10) і з масами М пзі таким чином, щоб маса відпускної партії зерна Мвп була забезпечена. Кількість партій зерна, що зберігаються, у відпускній партії

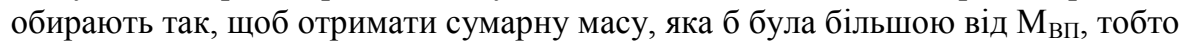

$$
M_{B \Pi}>\sum_{i} M_{\Pi 3 i}
$$

Надалі, для забезпечення необхідної маси продукту формують набір варіантів рішення, при яких $n-1$ партія насіння, що зберігається, буде входити до складу відпускної партії зерна у повному обсязі, а одна партія насіння до складу відпускної партії буде входити частково. Маса насіння, яку слід відвантажити з "часткової" партії, буде визначатися за формулою:

$$
M_{n}=M_{B \Pi}-\sum_{i=1}^{n-1} M_{\Pi З 3}
$$

Тоді відпускна партія насіння буде мати масу

$$
M_{\text {ВП }}=\sum_{i=1}^{n} M_{\Pi 3 i}
$$

та параметри, що визначаються за середньозваженою залежністю:

$$
Z_{j}=\frac{\sum_{i} Z_{\Pi 3 i j} \cdot M_{\Pi 3 i}}{M_{B \Pi}}
$$




\section{$\underline{5}$ ТЕОРІЯ І ПРАКТИКА АВТОМАТИЗАЦІЇ БІЗНЕС-ПРОЦЕСІВ}

Надалі визначають показник дисперсності за залежністю (10) та показник корисності варіанту рішення за залежністю (3).

Наступний варіант рішення від попереднього буде відрізнятися тим, що частковою буде вже інша відібрана партія насіння, що зберігається. При цьому кількість варіантів рішення буде відповідати кількості відібраних партії партій насіння, що зберігаються. Якщо ж відібрані партії насіння в повному обсязі без надлишків формують відпускну партію, то доцільний варіант рішення буде один.

Запропоновані підходи з метою їх працездатності було реалізовано програмно на прикладі елеватора насіння Одеського олієекстракційного заводу. У складі програми реалізовано кількісно-якісний облік насіння у силосах елеватора, а також алгоритми підтримки прийняття рішень при розміщенні насіння у силосах та при формуванні оптимальних за якісними показниками відпускних партій соняшникового насіння. Результати тестування алгоритмів підтримки прийняття рішень показали їх ефективність та доцільність для практичного впровадження.

Раніше запропоновані алгоритми було реалізовано та протестовано на базі елеватора олійних культур Олієпресового заводу Миронівського заводу з виробництва круп та комбікормів [5]

Основною метою сформульованих підходів до підтримки прийняття рішень персоналу елеватора у процесі управління запасами насіння дозволить знизити собівартість виробництва за рахунок зниження витрат на зберігання запасів. Досягнення мети забезпечується вирішенням наступних задач. Розв'язання задач оптимального розміщення партій насіння дозволить знизити витрати (переважно електроенергіï) на переміщення та обробку партій насіння за рахунок створення рівномірних за якісними параметрами партій насіння, що зберігаються. Рівномірне заповнення елеватора насінням дозволить зменшити нерівномірність навантаження на будівні конструкції елеватора, а значить знизити експлуатаційні затрати на обслуговування будівлі. Якщо в елеваторі зберігається кілька культур, то запропоновані підходи дозволять знизити імовірність змішування різних культур. Розв'язання задачі оптимального зберігання зерна дозволить знизити втрати насіння в масі і якості у процесі зберігання та зменшити імовірність економічно недоцільної обробки насіння. Розв'язання задач пошуку оптимальних режимів обробки насіння дозволить підвищити економічну ефективність та ступінь рентабельності процесів. Розв'язання задач формування оптимальних відпускних партій насіння дозволить направляти на виробництво сировину, що максимально відповідає запитам технології, та не завищувати якості насіння, що дозволяє знизити собівартість виробництва олії.

Література:

1. В Украине появится еще один маслоэкстракционный завод // www.ubr.ua - інтернет-портал UBR.;

2. Трішин Ф.А., Жигайло О. М., Гусаковський В.А. Автоматизована система простежуваності // Автоматизація технологічних і бізнес-процесів. - Одеса, 2012. - № 9,10. - с. 21-25.;

3. Жуковський Е.Й., Світий І.М. Модель прогнозування в системі підтримки прийняття рішення технолога зерносховища. // Удосконалення існуючих і розробка нових технологій для харчової та зернопереробної промисловості: Наук. пр. / Одес. держ. акад. харч. техн.- Одеса, 1999. - Вип. 19. - С.165-171.;

4. «Інструкція про ведення обліку й оформлення операцій із зерном і продуктами його переробки на хлібоприймальних та зернопереробних підприємствах», 2008 р;

5. Жуковский Э.И., Свитый И.Н., Булмаге М. Информационная система визуального учета зерна, хранимого в силосах элеватора. / Тез. докл. II Всеукраинской науч.-практ. конф. „Информационные технологии и автоматизация" - Одеса, 2009. - с. 35-36.

References

1. V Ukraine poyavitsya eshhe odin masloekstrakcionnyj zavod // www.ubr.ua - internet-portal UBR.;

2. Trishin F.A., Zhigajlo O. M., Gusakovskij V.A. Avtomatizovana sistema prostezhuvanosti // Avtomatizaciya texnologichnix i biznes-procesiv. - Odesa, 2012. - № 9,10. - s. 21-25.;

3. Zhukovskij E.J., Svitij I.M. Model prognozuvannya v sistemi pidtrimki prijnyattya rishennya texnologa zernosxovishha. // Udoskonalennya isnuyuchix i rozrobka novix texnologij dlya xarchovoï ta zernopererobnoï promislovosti: Nauk. pr. / Odes. derzh. akad. xarch. texn.- Odesa, 1999. - Vip. 19. - S.165-171.;

4. «Instrukciya pro vedennya obliku j oformlennya operacij iz zernom i produktami jogo pererobki na xliboprijmalnix ta zernopererobnix pidpri€mstvax», $2008 \mathrm{r}$;

5. Zhukovskij E.I., Svityj I.N., Bulmage M. Informacionnaya sistema vizualnogo ucheta zerna, xranimogo v silosax elevatora. / Tez. dokl. II Vseukrainskoj nauch.-prakt. konf. „Informacionnye texnologii i avtomatizaciya” Odesa, 2009. - s. 35-36. 